\title{
Comparison of two total RNA extraction protocols using the marine gorgonian coral Pseudopterogorgia elisabethae and its symbiont Symbiodinium sp.
}

\author{
Lory Z. Santiago-Vázquez \\ Center of Excellence in Biomedical and Marine Biotechnology \\ Department of Chemistry and Biochemistry \\ Florida Atlantic University \\ 777 Glades Rd., Boca Raton \\ FL 33431, USA \\ Tel: 5612973356 \\ Fax: 5612972759 \\ E-mail: santiago@fau.edu \\ Llanie K. Ranzer \\ Center of Excellence in Biomedical and Marine Biotechnology \\ Department of Chemistry and Biochemistry \\ Florida Atlantic University \\ 777 Glades Rd., Boca Raton \\ FL 33431, USA \\ Tel: 5612973356 \\ Fax: 5612972759 \\ E-mail: 1ranzer@fau.edu \\ Russell G. Kerr* \\ Center of Excellence in Biomedical and Marine Biotechnology \\ Department of Chemistry and Biochemistry \\ Florida Atlantic University \\ 777 Glades Rd., Boca Raton \\ FL 33431, USA \\ Tel: 5612973356 \\ Fax: 5612972759 \\ E-mail: rkerr@fau.edu
}

\begin{abstract}
Financial support: This work was funded by the American Cancer Society RSG-97-170-04-CDD, Florida Sea Grant R/LR-MB-14, and the National Science Foundation grant 0119011. L. Ranzer was partially funded by the Florida Atlantic University Delores A. Auzenne Fellowship. This material is based upon worked supported by the National Science Foundation under a grant awarded in 2003 to L.Z. Santiago-Vázquez (award \#0310283).
\end{abstract}

Keywords: dinoflagellate, RNA isolation, RNeasy minicolumns, trizol reagent.

Abbreviations: EDTA: ethylenediaminetetraacetic acid

PVP: polyvinylpyrrolidone

RT-PCR: reverse-transcriptase polymerase chain reaction

Marine invertebrates such as soft corals are important sources of secondary metabolites with promising biomedical applications and commercial value. RNA isolation in conjunction with reverse-transcriptase polymerase chain reaction (RT-PCR) are valuable tools utilized to study the molecular elements involved in secondary metabolite production and functional genomics. Two total RNA extraction protocols were compared using fresh tissue and flash frozen preparations from the coral Pseudopterogorgia elisabethae and from its symbiont Symbiodinium sp. isolated using RNeasy minicolumns (Qiagen ${ }^{\circledR}$ ) and Trizol reagent (Invitrogen ${ }^{\circledR}$ ). In general, higher yields were obtained by using Trizol reagent when compared to RNeasy. No significant differences were observed in RNA yield when live or flash frozen tissue was used. However, flash frozen holobiont tissue isolated by Trizol resulted in the highest RNA yield of all preparations analyzed. To conclude, both protocols are suitable for RNA isolation. Trizol is recommended if higher yields are the primary concern, but RNeasy is recommended if time is an issue.

The marine environment is a rich source of structurally unique natural products with bioactive metabolites that are being developed as therapeutic agents. Over 12,000 novel marine natural products have been discovered over the past

* Corresponding authors 
35 years (Faulkner, 2001), however large amounts of biomass of pharmacologically promising marine invertebrates cannot be harvested from nature without risking environmental damage. There is therefore an obligation to develop methods for supplying these products without disrupting the ecosystem and depleting the resource (Clark, 1996; Turner, 1996; Paterson and Anderson, 2005; Barsby, 2006). Molecular approaches such as cloning and expression of biosynthetic genes offer a promising approach to generate a supply of natural products (Bode and Müller, 2005; Wenzel and Müller, 2005) and these techniques often require the isolation of intact RNA.

The Caribbean gorgonian Pseudopterogorgia elisabethae is the source of potent antiinflammatory agents, the pseudopterosins (Look et al. 1986a; Look et al. 1986b). Evidence suggests that the biosynthetic machinery for pseudopterosin biosynthesis is located in P. elisabethae's symbiont, the dinoflagellate Symbiodinium sp. (Mydlarz et al. 2003). The lack of a lab-based supply of marine natural products such as the pseudopterosins has hampered their development and we have therefore been active in the development of a recombinant production method of such compounds.

Complications associated with isolating RNA from marine organisms include degradation by RNases, viscous polysaccharides that are co-extracted with nucleic acids throughout the extraction and purification processes, recalcitrant cellulosic walls, and difficulty adapting methodology designed for specific organisms (e.g., Ho et al. 1996; Hong et al. 1997; La Claire and Herrin, 1997; Chan et al. 2004). To our knowledge, there is limited information describing methods to successfully isolate intact RNA from corals and their symbionts. Current techniques are based on protocols designed for plant tissue, and typical lysis buffers contain guanidinium thiocyanate, lithium chloride, sodium lauroyl sarcosine solution (sarkosyl), ethylenediaminetetraacetic acid (EDTA), polyvinylpyrrolidone (PVP), and $\beta$-mercaptoethanol. The RNA is typically separated from proteins and other contaminants by phenol/chloroform or chloroform extractions. Qiagen's RNeasy ${ }^{\mathbb{B}}$ kit combines a guanidinium isothiocyanate lysis buffer with silica gel membrane purification. Invitrogen's Trizol ${ }^{\circledR}$ reagent is a monophasic solution of phenol and guanidinium isothiocyanate based on methodology developed by Chomczynski and Sacchi (1987). These commercially available kits have been successfully tested with many eukaryotic and prokaryotic species such as bacteria, yeast, and animal tissue and cells, but to our knowledge none have been tested with coral tissue or dinoflagellates.

Here we report a comparison of two commercial RNA extraction methods with slight modifications using Pseudopterogorgia elisabethae and its symbiont Symbiodinium sp. The objective of this study was to optimize an efficient RNA extraction method to be used for subsequent molecular studies and to show if commercially available kits are suitable for coral and dinoflagellate samples. We examined and quantified RNA yields from the holobiont (host-symbiont partnership) and the symbiont extractions, including a comparison of live and flash frozen samples. The resulting RNA was evaluated for long-term storage, and for its usefulness in RT-PCR (reverse transcriptase-PCR), DD (differential display) RT-PCR, and various other applications.

\section{MATERIALS AND METHODS}

\section{Supplies}

RNeasy Mini $\mathrm{Kit}^{\circledR}$ was obtained from Qiagen (Valencia, CA, USA). Trizol ${ }^{\mathbb{B}}$ Reagent was obtained from Invitrogen (Carlsbad, CA, USA). All nuclease-free plastics, and Metaphor and SeaKem agarose, were obtained from Fisher Scientific (Suwanee, GA, USA). Nuclease-free water was obtained from Promega (Madison, WI, USA).

\section{Sample collection}

Specimens of $P$. elisabethae were collected by SCUBA at Tennessee reef, Florida Keys, FL, USA, transported live to the lab, and placed in an aquarium at $\sim 29^{\circ} \mathrm{C}$ until used. Samples were also flash frozen at the Florida Keys, transported to the lab on dry ice, and stored at $-80^{\circ} \mathrm{C}$ until

Table 1. Summary of results from RNA extractions. Total time = includes Percoll cell isolation (if required), RNA isolation, DNase treatment if needed, and analysis by spectrophotometry and gel electrophoresis. $n=4,{ }^{*} n=3,{ }^{\#} n=2$

\begin{tabular}{|l|c|c|c|c|c|}
\hline \multicolumn{1}{|c|}{ Method } & Sample & $\begin{array}{c}\text { RNA yield } \\
\mathbf{\mu g} \mathbf{~ m g}_{\mathbf{1}} \text { tissue or } \\
\text { individual cell }\end{array}$ & $\begin{array}{c}\mathbf{A}_{\mathbf{2 6 0}} \text { : } \mathbf{A}_{\mathbf{2 8 0}} \\
\text { ratio }\end{array}$ & Bench time (hr) & Total time (hr) \\
\hline RNeasy & P. elisabethae frozen & 0.055 & 1.39 & $1 \mathrm{hr}$ & $3 \mathrm{hrs}$ \\
\hline Trizol & P. elisabethae frozen & 1.039 & 2.33 & $6 \mathrm{hrs}$ & $9 \mathrm{hrs}$ \\
\hline RNeasy & P. elisabethae live & 0.228 & 2.15 & $1 \mathrm{hrs}$ & $3 \mathrm{hrs}$ \\
\hline Trizol & P. elisabethae live & 0.536 & 2.46 & $6 \mathrm{hrs}$ & $9 \mathrm{hrs}$ \\
\hline RNeasy & Symbiodinium frozen & $2.693 \times 10^{-7}$ & 1.55 & $1 \mathrm{hr}$ & $8 \mathrm{hrs}$ \\
\hline Trizol & Symbiodinium frozen & $1.178 \times 10^{-6}$ & 2.42 & $6 \mathrm{hrs}$ & $14 \mathrm{hrs}$ \\
\hline RNeasy & Symbiodinium live & $2.556 \times 10^{-7}$ & 1.30 & $1 \mathrm{hr}$ & $8 \mathrm{hrs}$ \\
\hline Trizol & Symbiodinium live* & $7.880 \times 10^{-7}$ & 2.28 & $6 \mathrm{hrs}$ & $14 \mathrm{hrs}$ \\
\hline
\end{tabular}


used. This latter set of samples will be referred to as the flash-frozen material from here on. Attempts to store samples in RNAlater (Ambion, Texas, USA) were not successful as RNA could not be obtained from $P$. elisabethae, Symbiodinium, or any other coral or symbiont stored in this buffer.

\section{Symbiodinium cell isolation}

Symbiodinium cells were isolated and purified as we have previously reported (Mydlarz et al. 2003). Live coral was homogenized in a blender with $0.22 \mu \mathrm{m}$-filtered seawater, and the homogenate filtered through four layers of cheesecloth. Cells were pelleted by centrifugation $(1000 \mathrm{x}$ g) and washed $\sim 10$ times with $0.22 \mu \mathrm{m}$-filtered seawater until the supernatant was clear. Symbiodinium cells were purified by loading onto a Percoll step gradient $(20 \%, 40 \%$, and $80 \%$ ) and centrifuged for $10 \mathrm{~min}$ at $750 \mathrm{x} \mathrm{g}$, and the process repeated. Purified cells were washed to separate from Percoll, counted by using a hemocytometer and kept in sea water until used or immediately flash frozen and stored at $-80^{\circ} \mathrm{C}$ for 2 months to over 1 year. The Symbiodinium isolation procedure was repeated with flash frozen coral but we were consistently unable to obtain RNA from Symbiodinium using this tissue.

\section{RNA isolation by RNeasy minicolumns}

Total RNA isolation from coral and dinoflagellate cells was performed by grinding recommended amounts of tissue (30 mg for coral or $1 \times 10^{7}$ cells per minicolumn) with liquid Nitrogen $\left(\mathrm{LN}_{2}\right)$ in a frozen mortar and pestle taking care not to let the tissue thaw until it was placed in the appropriate lysis buffer supplied with the kit (Buffer RLT and $\beta$ mercaptoethanol). Powdered tissue was transferred to tubes filled with lysis buffer using sterile nuclease-free spatulas (Fisher Scientific). At this point the manufacturer's protocol was followed. The RNA was eluted twice in a total volume of $50 \mu \mathrm{l}$ of RNase-free $\mathrm{H}_{2} \mathrm{O}$. Samples were immediately aliquoted and stored at $-80^{\circ} \mathrm{C}$. RNA was quantified by measuring $\mathrm{A}_{260}$ absorbance in a Molecular Devices Spectra Max Plus plate-reader. Purity was assessed by calculating the $\mathrm{A}_{260} / \mathrm{A}_{280}$ ratio. Samples were loaded (0.5-1.0 $\mu \mathrm{g}$ of RNA) in a $1.2 \%$ agarose gel, run at $100 \mathrm{~V}$ for $1.5 \mathrm{hrs}$ and stained with ethidium bromide. Gels were visualized using a Typhoon 9410 variable mode imager (Amersham, USA).

\section{RNA isolation by Trizol}

Tissue or cells were disrupted as described above $(100 \mathrm{mg}$ coral sample or $1 \times 10^{7}$ cells per assay). Powdered tissue was placed in $1 \mathrm{ml}$ Trizol $^{\circledR}$ reagent and the manufacturer's protocol was followed with the exception of the following modifications. The protocol suggests precipitating RNA at room temperature; however, precipitation at $-20^{\circ} \mathrm{C}$ proved to be more effective. Also, after the RNA pellet was air dried, RNase-free water was added to the pellet, and solubilization was achieved by incubating at $55^{\circ} \mathrm{C}$ for 10 min. Samples were quantified and visualized, aliquoted, and stored at $-80^{\circ} \mathrm{C}$ as described above.

\section{RNA precipitation}

Samples were precipitated in the presence of $0.5 \mathrm{M}$ ammonium acetate. GlycoBlue (Ambion) was added to give a final concentration of $50 \mu \mathrm{g} / \mathrm{ml}$ to aid in pellet
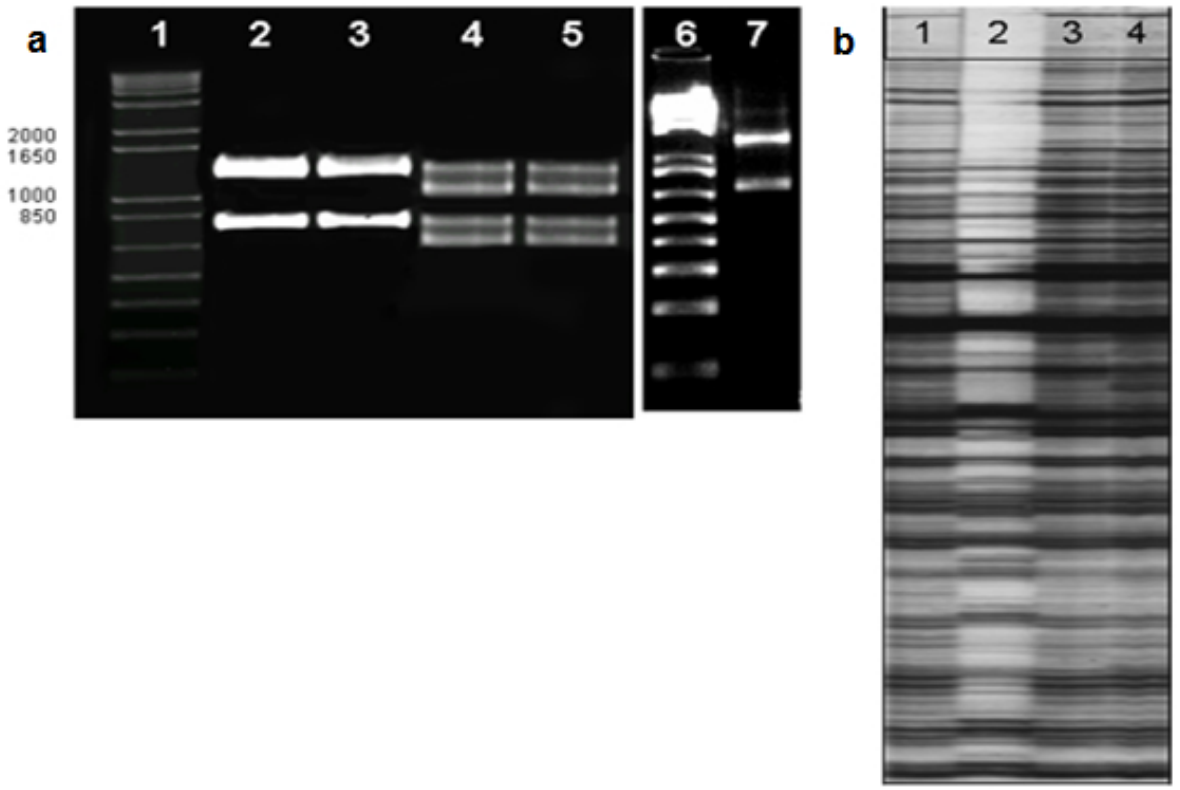

Figure 1. RNA isolation and subsequent application with RT-PCR.

(a) RNA $(1 \mu \mathrm{g})$ isolated from $P$. elisabethae. 1 and 6: $1 \mathrm{~kb}$ DNA Plus ladder, 2-3: Frozen $P$. elisabethae isolated using Trizol, 4-5: Live $P$. elisabethae isolated using Trizol. 7: Live $P$. elisabethae isolated using RNeasy.

(b). Region of a differential display RT-PCR gel showing CDNA transcripts induced for terpene production in $P$. elisabethae and its algal symbiont. Original RNA was isolated using RNeasy method. Lane 1 P. elisabethae (control), Lane 2 Purified Symbiodinium sp. (control), Lane 3 and $4 P$. elisabethae cDNA transcripts representing differential gene expression responses from the addition of $150 \mu \mathrm{M}$ Methyl Jasmonate. 
visualization and $100 \%$ ethanol was added at twice the initial volume. The RNA was left to precipitate at $-80^{\circ} \mathrm{C}$ overnight. RNA was pelleted by centrifugation at $>8,000 \mathrm{x}$ $\mathrm{g}$ for $20 \mathrm{~min}$. The supernatant was decanted, the pellet was washed with $70 \%$ ethanol, air-dried for $10 \mathrm{~min}$, and brought back into solution by adding RNase-free water and incubating at $55^{\circ} \mathrm{C}$ for $10 \mathrm{~min}$.

\section{RESULTS}

\section{Holobiont RNA yields}

Yields of RNA from P. elisabethae holobiont obtained through both protocols varied (Table 1). The amount of initial tissue used with Trizol ${ }^{\circledR}(100 \mathrm{mg})$ is higher than that required per RNeasy minicolumn $(30 \mathrm{mg})$. A typical Trizol $^{\circledR}$ assay of $P$. elisabethae yielded $\sim 50-100 \mu \mathrm{g}$ of RNA compared to $\sim 6-17 \mu \mathrm{g}$ of RNA for RNeasy ${ }^{\circledR}$. However, when samples were normalized per mg of weight of coral sample, the Trizol ${ }^{\mathbb{B}}$ method resulted in $\sim 0.5-1.0 \mu \mathrm{g}$ of RNA while the RNeasy protocol yielded $\sim 0.05-0.2 \mu \mathrm{g}$ of RNA per $\mathrm{mg}$ of material (Table 1). The largest difference observed was between $P$. elisabethae's flash frozen samples where Trizol $^{\circledR}$ samples resulted in an increase in RNA amount by a factor of 18.9 over the RNeasy ${ }^{\circledR}$ samples. For all other holobiont samples the differences were 2-4 times higher for Trizol ${ }^{\mathbb{R}}$ RNA yields when compared to RNeasy ${ }^{\mathbb{B}}$ yields.

\section{Symbiodinium RNA yields}

RNA yields obtained from Symbiodinium cells $\left(1 \times 10^{7}\right)$ are described in Table 1. These yields were found to be 3-4 times higher for all Trizol ${ }^{\mathbb{R}}$ samples when compared to RNeasy $^{\mathbb{B}}$. Symbiodinium live cell RNA isolated with Trizol $^{\mathbb{B}}$ produced the highest amount of RNA (total of $17.18 \mu \mathrm{g}$ RNA or $7.9 \times 10^{-7} \mu \mathrm{g}$ RNA per cell). It was noted that the RNeasy ${ }^{\mathbb{B}}$ lysis buffer did not successfully lyse all cells and a pellet of cells was observed by microcroscopy after lysis and centrifugation through the provided minishredder columns. This could explain the lower yield for RNeasy ${ }^{\circledR}$ compared to Trizol $^{\circledR}$ when using Symbiodinium cells. In contrast, all cells were successfully lysed with Trizol ${ }^{\circledR}$ reagent. The overall yields seem to be comparable to those reported for Trizol ${ }^{\circledR}$ and RNeasy ${ }^{\circledR}$ cell yields by the manufacturers.

\section{RNA quality}

The issue of RNA quality was assessed by calculating the $\mathrm{A}_{260} / \mathrm{A}_{280}$ ratio to determine DNA and protein contamination. Ratios for all types of samples examined ranged from 1.30 to 2.15 for RNeasy samples and 2.28 to 2.46 for Trizol $^{\circledR}$ samples (Table 1). There were no significant differences between live and frozen samples. The closest ratio to 2.0 (indicative of pure RNA) was obtained for $P$. elisabethae RNA isolated through RNeasy ${ }^{\mathbb{B}}$ (2.15). The quality of RNA was inspected by agarose gel electrophoresis (Figure 1). All samples showed bands typical of undegraded RNA. It should be noted that samples isolated through Trizol ${ }^{\circledR}$ showed the sharpest and cleanest bands.

The utility of the isolated RNA was tested by performing reverse-transcriptase PCR (RT-PCR) using various available methodologies based both on random hexamers or polyA-anchored primers to build the first strand cDNA and with gene-specific or degenerate primers for the PCR step. RNA isolated through both methodologies was suitable for RT-PCR (data not shown). Additionally, RNA isolated using the RNeasy $^{\circledR}$ method was used to identify differentially expressed genes in the coral and its algal symbiont. P. elisabethae and Symbiodinium sp. RNA was isolated, reverse transcribed into cDNA using an anchored oligo dT primer and subsequently amplified by PCR with random hexamers (Figure 1).

\section{DISCUSSION}

We were able to successfully isolate high quality RNA by grinding whole coral tissue or dinoflagellate cells (flash frozen and stored at $-80^{\circ} \mathrm{C}$, or live) using a chilled mortar and pestle with $\mathrm{LN}_{2}$. This is in contrast to Weis et al. (1998) who were not able to successfully use this method of tissue disruption for the isolation of RNA from anemones and corals. A key aspect to isolating clean RNA using Qiagen's RNeasy ${ }^{\circledR}$ minicolumns was not to exceed the recommended amount of tissue by more than $20 \%$. It is critical to stay within the recommended amounts $(30 \mathrm{mg}$ coral tissue or $1 \mathrm{x}$ $10^{7}$ cells/column) if the coral or symbionts release a high amount of mucus when working with this protocol. If the tissue does not produce a noticeable amount of mucus, one can overload the columns by as much as $20-30 \%$. Trizol ${ }^{\circledR}$ is a more flexible protocol when higher amounts than the recommend weight/cell number are used, even when the coral has a high concentration of mucus. We have used as much as double the recommended amount of tissue and have still obtained satisfactory results although the RNA tends to be more impure as higher amounts of tissue are used.

When compared to the manufacturer's results, RNA yields for the holobiont obtained through this study were more than 10 times lower than typical yields obtained through RNeasy ${ }^{\circledR}$ by Qiagen ${ }^{\circledR}$ model tissues but are comparable to those reported for Trizol ${ }^{\circledR}$ using Invitrogen's model tissues (i.e., liver, spleen, kidney). To the best of our knowledge there are no reports on RNA yields from corals, thus preventing a direct comparison. However, we can compare our findings with those reported from algae since they have similar physiological characteristics and complications during RNA isolation. Holobiont RNA yields obtained through Trizol are 2-4 times higher than those reported for algae RNA by Hong et al. (1997) (0.008-0.243 $\mu \mathrm{g}$ RNA/mg tissue) and 1000 times higher than those reported by Chan et al. (2004) (0.65 x $10^{-3}-1.14 \times 10^{-3} \mu \mathrm{g} \mathrm{RNA} / \mathrm{mg}$ tissue; $)$. In contrast, RNA yields obtained through $\mathrm{RNeasy}^{\circledR}$ are comparable to those by Hong et al. (1997) but still between 50-300 times higher than those reported by Chan et al. (2004). Comparison of our RNA yields obtained from dinoflagellate cells with those from other extractions from dinoflagellates are not possible due to the lack of such 
literature.

Absorbance ratios $\left(\mathrm{A}_{260} / \mathrm{A}_{280}\right)$ between 1.8-2.0 can be used to determine the quality of a RNA preparation. The ratios reported for all samples in this study are slightly higher than those reported by others (Hong et al. 1997; Chan et al. 2004) but well within the typical range. When analyzing the RNA bands by gel electrophoresis, a key difference was observed between live and frozen tissue (Figure 1). Frozen tissue produced a single set of bands that are presumably the typical 28S and $18 \mathrm{~S}$ bands of eukaryotic RNA whereas live tissue produced a double banding pattern. We assume that the second set of bands belongs to prokaryotic (16S and $23 \mathrm{~S})$ or fungal RNA (18S or $26 \mathrm{~S} / 28 \mathrm{~S})$ as these organisms have rRNA with smaller sizes. These organisms are known to cohabit within $P$. elisabethae's tissues (unpublished data). Although the double banding pattern of each rRNA is an unusual observation, it has proven to be a reproducible characteristic within RNA isolations from live specimens. We speculate a loss of some RNA upon the flash freezing of the samples and therefore do not observe the double banding pattern for such tissue. Importantly, we have been able to clone genes of eukaryotic and prokaryotic origin using RNA isolated through either technique.

The bench time required by each method was significantly different although RNA was obtained in under one day for both methods. RNeasy ${ }^{\circledR}$ involves a significantly shorter protocol and DNase treatment can be achieved on the column (without the DNase treatment the protocol time is only $30 \mathrm{~min}$; Table 1). Trizol ${ }^{\circledR}$ is a relatively longer protocol and the RNA has to be treated for DNA contamination separately.

In conclusion, both protocols were found to be suitable for the isolation of total RNA from $P$. elisabethae and from its symbiont Symbiodinium sp. If time is of concern, we recommend the use of $\mathrm{RNeasy}^{\circledR}$ due to its simplicity. However, if large quantities of RNA are desired, it is advisable to use Trizol $^{\circledR}$ since this method produces significantly larger amounts of RNA than the RNeasy ${ }^{\circledR}$ protocol and it was found to be easily scalable. In regards to yields, we conclude that the best approach to isolate RNA from the holobiont is to use flash frozen material and Trizol $^{\circledR}$ whereas for Symbiodinium cells the best results were obtained using live cells and Trizol ${ }^{\circledR}$. These methods can also be used with other corals and their symbionts with similar results.

\section{REFERENCES}

BARSBY, Todd. Drug discovery and sea hares: bigger is better. Trends in Biotechnology, January 2006, vol. 24, no. 1, p. 1-3.

BODE, Helge B. and MÜLLER, Rolf. The impact of bacterial genomics on natural product research. Angewandte Chemie International Edition, October 2005, vol. 44 , no. 42 , p. $6828-6846$.

CHAN, Cheong-Xin; TEO, Swee-Sen; OTHMAN, Rofina
Yasmin; PHANG, Siew-Moi and HO, Chai-Ling. Optimisation of RNA extraction from Gracilaria changii (Gracilariales, Rhodophyta) Journal of Applied Phycology, August 2004, vol. 16, no. 4, p. 297-301.

CHOMCZYNSKI, Piotr and SACCHI, Nicoletta. Singlestep method of RNA isolation by acid guanidinium thiocyanate-phenol-chloroform. Analytical Biochemistry, April 1987, vol. 162, no. 1, p. 156-159.

CLARK, Alice M. Natural products as a resource for new drugs. Pharmaceutical Research, August 1996, vol. 13, no. 8, p. 1133-1141.

FAULKNER, D. John. Marine natural products. Natural Products Reports, September 2001, vol. 18, p. 1-49.

HO, Chai-Ling; PHANG, Siew-Moi; SINNAPPAH, Netta Devi and PANG, Tikki. Molecular approaches in the taxonomy of the red and brown seaweeds. In: CHAUDHARY, B.R. and AGRAWAL, S.B. eds. Cytology, genetics and molecular biology of the algae. Amsterdam, SPB Academic Publishing, 1996, p. 351-362.

HONG, Yong-Ki; SOHN, Chul Hyun; LEE, Ki Wan and KIM, Hyung Geun. Nucleic acid extraction from seaweed tissues for polymerase chain reaction. Journal of Marine Biotechnology, May 1997, vol. 5, no. 2-3, p. 95-99.

LA CLAIRE II, John W. and HERRIN, David L. Coisolation of high-quality DNA and RNA from coenocytic green algae. Plant Molecular Biology Reporter, September 1997, vol. 15 , no. 3, p. 263-272.

LOOK, Sally A.; FENICAL, William; JACOBS, Robert S. and CLARDY, Jon. The pseudopterosins: antiinflammatory and analgesic natural products from the sea whip Pseudopterogorgia elisabethae. Proceedings of the National Academy of Sciences of the United States of America, September 1986a, vol. 83, no. 17, p. 6238-6240.

LOOK, Sally A.; FENICAL, William; MATSUMOTO, Gayle K. and CLARDY, Jon. The pseudopterosins: a new class of anti-inflammatory and analgesic diterpene pentosides from the marine sea whips Pseudopterogorgia elisabethae (Octocorallia). The Journal of Organic Chemistry, December 1986b, vol. 51, no. 26, p. 5140-5145.

MYDLARZ, Laura D.; JACOBS, Robert S.; BOEHNLEIN, Jennifer and KERR, Russell G. Pseudopterosin biosynthesis in Symbiodinium sp., the dinoflagellate symbiont of Pseudopterogorgia elisabethae. Chemistry and Biology, November 2003, vol. 10, no. 11, p. 1051-1056.

PATERSON, Ian and ANDERSON, Edward A. The renaissance of natural products as drug candidates. Science, October 2005, vol. 310, no. 5747, p. 451-453.

TURNER, David M. Natural product source material used in the pharmaceutical industry: the Glaxo experience. Journal of Ethnopharmacology, April 1996, vol. 51, no. 1- 
3, p. 39-44.

WEIS, Virginia M.; VON KAMPEN, Jan and LEVINE, R. Paul. Techniques for exploring symbiosis-specific gene expression in cnidarian/algal associations. In: COOKSEY, Keith E. ed. Molecular Approaches to the Study of the Ocean. London, Chapman and Hall, 1998, p. 435-448.

WENZEL, Silke C. and MÜLLER, Rolf. Recent developments towards the heterologous expression of complex bacterial natural product biosynthetic pathways. Current Opinion in Biotechnology, December 2005, vol. 16 , no. 6, p. 594-606.

Notes: Any opinions, findings, and conclusions or recommendations expressed in this publication are those of the authors and do not necessarily reflect the views of the National Science Foundation. The experiments comply with the current laws of the state of Florida , USA. This is contribution number P200625 from the Center of Excellence in Biomedical and Marine Biotechnology. 